\title{
The Impact of the Preparation Period on Endurance at Football Players U16
}

\author{
Jovan Gardasevic ${ }^{1}$, Dusko Bjelica', Marin Corluka² \\ 'University of Montenegro, Faculty for Sport and Physical Education, Niksic, Montenegro, ${ }^{2}$ University of Mostar, Faculty of Mathematics and Science \\ Education, Mostar, Bosnia and Herzegovina
}

\begin{abstract}
The main aim of the research was to identify a level of quantitative changes of the endurance with U16 football players under the influence of the programmed football training of a six weeks preparation period. The training programme covered forty-four training units. The research was made on a sample of 120 football players U16. To estimate the endurance three tests have been used: Cooper test, Running $15 \mathrm{~m}$ long distance for $90 \mathrm{~s}$, and Pin running persistence. In the area of comparative statistics, we used discriminant parametric procedure t-test for big paired samples. It can be concluded that there are statistically significant differences in all three variables to estimate the endurance. This confirmed the hypothesis that the expected significant positive quantitative changes of endurance influenced by the proposed model of training in preparation period with football players U16. The authors were guided by the fact that this kind of training program in preparation period is very effective in terms of raising the endurance level with football players U16. The obtained results can be directed towards innovation plans and programs in the preparation period, and the adaptation of the same needs of the respective population.
\end{abstract}

Key words: football, preparation period impact, endurance

\section{Introduction}

Football is a sport that is characterized by numerous and varied complex dynamic kinesiology activities that are characterized by a large number of cyclic and acyclic movements (Gardašević, \& Goranović, 2011; Gardašević, \& Bjelica, 2013; Sermaxhaj, Popovic, Bjelica, Gardasevic, \& Arifi, 2017; Corluka, \& Vasiljevic, 2018). It is evident that all four moments of play (Gardašević, Bjelica, \& Popović, 2015; Gardasevic, 2015), possession of the ball, the opponent's possession of it, the transformation after winning the ball and the transformation after losing the ball depends on the ability of players to perform certain movements of varying intensity, in different directions and the different sections of the field (Gardašević, Georgiev, \& Bjelica, 2012; Gardašević, Bjelica, \& Vasiljević, 2016a ; Gardasevic, Bjelica, \& Vasiljevic, 2017a; Gardašević et al., 2015). They must have developed basic and specific motor abilities (Vasiljević, Gardašević, \& Bojanić, 2013; Bjelica, Popović, \& Gardašević, 2016a). One of the basic motor skills, which should be at a high level, is endurance. Most of the elements in football game, especially those with the ball, are very complex (Gardašević, Bjelica, \& Vasiljević, 2016b; Gardasevic, Bjelica, Milasinovic, \& Vasiljevic, 2016). For their improvement and impeccable application in the game, it is necessary first to have the whole motor preparations (Gardašević, Vasiljević, \& Bojanić, 2015; Gardaševic, \& Vasiljević, 2016). The physical strength has a great importance in football (Gardaševic, \& Bjelica, 2014a; Gardasevic, \& Bjelica, 2014b Bjelica, Popović, \& Gardašević, 2016b). A specific strength with football player is reflected by the strength reflection while jumping, the pushing strength with sprint, strength of stopping and pushing while changing the moving direction, strength of kicking by foot and with a head, strength of throwing the ball with a hand, stability on the ground and in the air, in duels (Gardaševic, \& Bjelica, 2014). One of the factors that affect the strength is the football players is their age (Bjelica, 2003; 2004; 2005). In child's development the strength increases with increasing a muscle size. Psychomotor strength, primarily static and repetitive, according to some authors is $50 \%$ innate, and

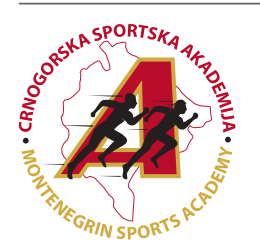

Correspondence:

J. Gardasevic

University of Montenegro, Faculty for Sport and Physical Education, Narodne omladine bb, Niksic, Montenegro

E-mail:jovan@ac.me 
systematic training can have a significant effect on it.

The endurance of football players may be the most important ability (Gardašević, 2010). It is defined as the ability to perform an activity for a long time period without reducing the effectiveness of this activity, i.e. the ability of endure a physical effort for a long time. The coefficient of inheritance of this ability is $70-80 \%$. The endurance is based on the efficiency of the functioning of the regulatory mechanisms which are manifested in energy reserves (ATP, creatine phosphate and oxygen) and functional quality of energy potential (energy processes). We distinguish three types of endurance to a man: Aerobic endurance (from $5 \mathrm{~min}$ to several hours), Anaerobic lactate endurance (from 3 to 5 minutes) and Anaerobic alactate endurance (from 15 to 20 seconds). The main objective of this study was to determine the level of quantitative changes of endurance in football players U16, under the influence of a programmed football training which included one preparatory period of forty-two days.

\section{Methods}

This was a longitudinal study with an aim that in the two time-varying points determine quantitative changes of endurance in football players ( 15 year \pm 6 months) under the influence of programmed training process, which included a summer preparation period for the competition season in a unique cadet league of Montenegro and the cadet league middle region of Montenegro. The training program lasted 42 days and was carried out on the auxiliary football field of FC Sutjeska Niksic. The training program included 44 trainers units, within which 8 friendly matches were played. For data processing only the results of those respondents who have undergone a complete program of work and who have joined the initial and final measurement are taken. This study included a sample of 120 young football players U16 of 4 teams, all from Niksic. Before programmed work all respondents had passed medical check-ups to make sure they could access the training process. When selecting the instruments (tests) it was taken into account that they meet the basic metric characteristics (Gardašević, \& Bjelica, 2012; Gardaševic, Bjelica, Georgiev, \& Popović, 2012; Bjelica, Gardasević, Georgiev, Popović, \& Petković, 2012), which means the appropriate age and objective material and spatial conditions. For the assessment of endurance the following tests were used: 1. Cooper test (MCPT), 2. Running $15 \mathrm{~m}$ long distance for $90 \mathrm{~s} \mathrm{(MRLD),} \mathrm{3.} \mathrm{Pin} \mathrm{running} \mathrm{persistence}$ (MPRP).

Considering that these are a cadet age players (15-year olds \pm 6 months), in a sensitive period of psychophysical development, program is tailored specifically to their age, taking into account the time spent in the previous training process. Time structure of the training ranged from 60 to 120 minutes, depending on the goals and objectives of the training unit and it was divided into 3 phases:
- Introductory-preparatory part (25-30\% of the duration of training)

- The main part (60-65\% of the duration of the training)

- The final part (up to $10 \%$ of the duration of training)

In the introductory-preparatory part of the training the emphasis was on raising the operating temperature in children. As a tool a various elementary games with a ball were used that enabled work on the elementary basics of technique and tactics, also the various polygons with exercises coordination were used. A variety of games and exercises to increase joint mobility and strengthen muscles also applied at this stage. At the first stage of the main part of the training the intensity is slightly increased compared to the warm-up phase and the training program was implemented through a variety of ball games. With a game method the respondents were taught and practiced football skills through a large number of repetitions. At the second stage of the main part of the training the players mostly had a free game on two goals that allowed them a creative activities and highlight of individual, imagination, independent thinking and hard work, applying the elements that teach by the method of the game from the first stage of the main part, and thus strengthening the willing quality. At this stage of the training the intensity was the greatest. At the final part of the training the task was lowering the physiological curve to an optimum level, and low-intensity activities were used: stretching and relaxation exercises, competitive game of penalty kicks, free kicks.

Data obtained from the survey were analyzed using descriptive and comparative statistics. In the area of descriptive statistics for each variable both in the initial and the final state central and dispersion parameters were processed as well as measures of asymmetry and flatness. The hypothesis of normal distribution of results was tested on the basis of Kolmogorov and Smirnov test. In the area of comparative statistics, to determine differences in the variables used to estimate the endurance at the start (initial state) and at the end (final state) of the training program in the preparation period, we used the discriminative parametric procedure t-test for large dependent samples.

\section{Results}

In Tables 1 and 2 are shown the basic descriptive statistical parameters of variables for estimations of the endurance in the initial and final measurement, where the values of central and dispersion tendency were calculated: arithmetic mean (Mean), standard deviation (Std. D.), standard error of arithmetic mean (Std. E.), minimum (Min) and maximum (Max) values, the range of results (Range), the curvature coefficient (Skewness) and elongation (Kurtosis), as well as the values of Kolmogorov and Smirnov test (K-S test). First the central and dispersion parameter of variables for assessing endurance in the initial state were analyzed (Table 1).

Table 1. Central and depression parameter of variables for assessing endurance in the initial state

\begin{tabular}{lccccccccc}
\hline Variables & Mean & Std. D. & Std. E. & Min. & Max. & Range & Skewness & Kurtosis & K-S test \\
\hline MCPTI & 2689.50 & 169.09 & 15.44 & 2310 & 3050 & 740 & 0.10 & -0.60 & 0.80 \\
MRLDI & 307.86 & 16.64 & 1.52 & 270 & 335 & 65 & -0.21 & -0.92 & 0.05 \\
MPRPI & 1816.67 & 125.19 & 11.43 & 1540 & 2060 & 520 & -0.05 & -0.87 & 0.31 \\
\hline
\end{tabular}

By analyzing the central and dispersion parameters of variables for assessing the endurance in the initial state-it can be noticed that the results belong to extremely homogeneous sets in all three variables. The negative values of the skewness with variable Running $15 \mathrm{~m}$ long distance for $90 \mathrm{~s}$ (MRLD) and variable Pin running persistence (MPRP) showing a negative asymmetry and the inclination to better results in the sample. Negative values of kurtosis in all three variables talking about mild platykurtic curve which the results of all these three variables form. Values of Kolmogorov and Smirnov test shows that the results are normally distributed.

Central and dispersion parameters of variables for estimation of the endurance in the final measurement showed the following values (Table 2) 
Table 2. Central and dispersive parameters of variables for estimation of the endurance in the final measurement

\begin{tabular}{lccccccccc}
\hline Variables & Mean & Std. D. & Std. E. & Min. & Max. & Range & Skewness & Kurtosis & K-S test \\
\hline MCPTF & 2848.63 & 151.35 & 13.82 & 2570 & 3220 & 650 & 0.22 & -0.53 & 0.84 \\
MRLDF & 322.60 & 15.35 & 1.40 & 290 & 350 & 60 & -0.14 & -0.80 & 0.10 \\
MPRPF & 1905.17 & 131.79 & 12.03 & 1600 & 2165 & 540 & -0.08 & -0.81 & 0.42 \\
\hline
\end{tabular}

By analyzing the central and dispersion parameters of variables for estimation of the endurance in the final stage-it can be noticed that here as well the values of arithmetic means in all three variables are at a higher level than in the initial state. The results belong to extremely homogeneous sets in all three variables. The values of skewness and kurtosis are in the range of -1 to +1 , which means that the inclination and elongation of the results do not deviate statistically significantly from the normal schedule. The values of Kolmogorov and Smirnov test shows that the results are normally distributed in all three variables.

To determine the statistical significance (significance) of differences in arithmetic means (partial quantitative changes) of variables for estimation of the endurance, the t-test was applied to for large dependent samples. The values of t-test were on the level of significance (Sig.) from 0.01 ( $\mathrm{p} \leq .01)$ in all the variables for the evaluation of endurance. The differences of arithmetic means of the initial and the final measurement of variables for evaluating endurance are shown in Table 3.

Table 3. The values of t-test between the arithmetic means of the initial and the final measurement of variables for evaluating endurance

\begin{tabular}{|c|c|c|c|c|c|c|c|}
\hline & Variables & Mean & Std. D. & Std. E. & Correlation & $\mathrm{t}$-test & Sig. \\
\hline \multirow{2}{*}{ Par 1} & MCPTI & 2689.50 & 169.09 & 15.44 & \multirow{2}{*}{0.91} & \multirow{2}{*}{-24.31} & \multirow{2}{*}{0.00} \\
\hline & MCPTF & 2848.63 & 151.35 & 13.82 & & & \\
\hline \multirow{2}{*}{ Par 2} & MRLDI & 307.86 & 16.64 & 1.52 & \multirow{2}{*}{0.98} & \multirow{2}{*}{-46.34} & \multirow{2}{*}{0.00} \\
\hline & MRLDF & 322.60 & 15.35 & 1.40 & & & \\
\hline \multirow{2}{*}{ Par 3} & MPRPI & 1816.67 & 125.19 & 11.43 & \multirow{2}{*}{0.99} & \multirow{2}{*}{-42.99} & \multirow{2}{*}{0.00} \\
\hline & MPRPF & 1905.17 & 131.79 & 12.03 & & & \\
\hline
\end{tabular}

Based on the results gained it can be noted that there are statistically significant differences in all variables for estimation of the endurance, and therefore can be said that there was a statistically significant positive partial effects of the training program in the preparation period, and the t-test values were significant at the reliability level $\mathrm{p}<.01$ for all variables for estimation of the endurance.

\section{Discussion}

On the basis of the obtained parameters it can be concluded that the statistically significant partial quantitative effects (changes) in all the variables for estimation of the endurance obtained as a result of the training program applied in the preparation period. The method of work that has been applied in this training program abounds running with varying intensity, so that the positive transformations are not unexpected (Gardaševic, \& Bjelica, 2014; Gardašević, Bjelica, Popović, \& Milašinović, 2016; Gardasevic, Popovic, \& Bjelica, 2016; Gardasevic, Bjelica, \& Vasiljevic, $2017 \mathrm{~b})$. In this age it comes to an increase in biological growth and development of muscles, increase of muscle cross-section, which can certainly contribute to positive results (Gardasevic, Bjelica, \& Vasiljevic, 2016). Based on the results of t-test for large dependent samples, with the variables for estimation of the endurance the statistically significant differences were determined in all pairs of variables between the initial and final states, at the level of statistical significance (significance), $\mathrm{p}<.01$. In this research the authors were guided by the fact that such a training program of work in preparation period is a very efficient way of working in terms of raising the level of endurance with football players U16 (Vasiljevic, 20017). The authors conclude that the summer period of 42 days, at football players U16, with such training work program, is optimal for lifting the endurance to the level required for the competition. The gained results can be directed towards innovation of plans and programs of work in the preparation period, and adjusting the same to the needs of the population concerned.

\section{Acknowledgements}

There are no acknowledgements.

\section{Conflict of Interest}

The authors declare there are no conflict of interest.

Received: 12 October 2017| Accepted: 15 December 2017

\section{References}

Bjelica, D. (2003). Uticaj fudbalskog treninga na biomotorni status kadeta Crne Gore. Doktorska disertacija. Beograd: Fakultet sporta i fizickog vaspitanja.

Bjelica, D. (2004). Zavisnost tjelesnih sposobnosti od sportskog treninga kod populacije fudbalskih kadeta Crne Gore. Sport Mont, II(4), 58-71.

Bjelica, D. (2005). Sportski trening i njegov uticaj na antropomotoricke sposobnosti fudbalera cetrnaestogodisnjaka mediteranske regije u Crnoj Gori. Sport Mont, III(8-9), 26-41.

Bjelica, D., Gardasević, J., Georgiev, G., Popović, S., \& Petković, J. (2012). Validity of the Applied Motor Tests for Estimating Basic Motor Abilities of Football Players-U15. Research in physical education, sport and health 1(2), 21-25.

Bjelica, D., Popović, S., \& Gardašević, J. (2016a). Modeli fizičke pripreme vrhunskih sportaša i doziranje opterećenja. Zbornik radova 14. godišnje međunarodne konferencije "Kondicijska priprema sportaša" (185-189). Zagreb: Udruga kondicijskih trenera Hrvatske.

Bjelica, D., Popović, S., i Gardašević, J. (2016b). Opći principi planiranja i programiranja fizičkih priprema sportaša. Zbornik radova 14.godišnje međunarodne konferencije "Kondicijska priprema sportaša" (190-192). Zagreb: Udruga kondicijskih trenera Hrvatske.

Corluka, M., \& Vasiljevic, I. (2018). Differences in the Morphological Characteristics and Body Composition of Football Players in Montenegro. Journal of Anthropology of Sport and Physical Education, 2(1), 3-7. doi: 10.26773/jaspe.180101

Gardašević, J. (2010). Efekti programiranog rada u pripremnom periodu na transformaciju bazično-motoričkih i situaciono-motoričkih sposobnosti kod fudbalera kadetskog uzrasta. Neobjavljena magistarska teza. Nikšić: Fakultet za sport i fizičko vaspitanje.

Gardašević, J., \& Goranović, K. (2011). Efekti programiranog rada u pripremnom periodu na transformaciju eksplozivne snage kod fudbalera kadeta. Sport Mont, IX(28-30), 55-62.

Gardašević, J., Georgiev, G., \& Bjelica, D. (2012). Qualitative changes of basic motor abilities after completing a six-week training programme. Acta Kinesiologica, 6(1), 70-74. 
Gardašević, J., Bjelica, D., Georgiev, G., \& Popović, S. (2012). Transformation of situational motor abilities with football players-cadets. Proceeding book XVI International Scientific Congress "Olympic Sports and Sport for All" \& VI International Scientific Congress "Sport, Stress, Adaptation" (373377). Sofia: National Sports Academy "Vassil Levski".

Gardašević, J., \& Bjelica, D. (2012). Valjanost situacijsko-motoričkih testova kod fudbalera kadeta u dobi od 15 godina (U15). Sport Mont, $X(34-36)$ 488-493.

Gardašević, J., \& Bjelica, D. (2013). Efekti programiranog trenažnog rada u trajanju od šest nedjelja na transformaciju fleksibilnosti kod fudbalera kadetskog uzrasta. Sport Mont, XI(37-39), 212-217.

Gardaševic, J., \& Bjelica, D. (2014a). The effects of the training in the preparation period on the dribbling speed with fifteen years old football players. Book of Abstracts of the 11th International Scientific Conference on Transformation Process in Sport "Sport Performance" (22-23). Podgorica: Montenegrin Sports Academy.

Gardasevic, J., \& Bjelica, D. (2014b). Efekti rada u pripremnom periodu na brzinu vođenja lopte petnaestogodišnjih fudbalera. Sport Mont, XII(4042), 160-166.

Gardašević, J., Vasiljević, I., \& Bojanić, D. (2015). Six-week preparation period and its effects on coordination transformation with football players under 16. Book of Abstracts 11 th International Scientific Conference Management, Sport, Olympism (36). Beograd: Fakultet za menadžment u sportu, Alfa univerzitet.

Gardasevic, J. (2015). The effects of the training in the preparation period on the agility transformation with cadet level football players. Book of Abstracts of the 12th International Scientific Conference on Transformation Process in Sport "Sport Performance" (76-77). Podgorica: Montenegrin Sports Academy.

Gardašević, J., Vasiljević, I., Bojanić, D., Muratović, A., Ljubojević, M., Milašinović, R., \& Bubanja, M. (2015). Six-week Preparation Period and its Effects on Transformation Movement Speed with Football Players Under 16. Book of Abstracts, International Scientific Conference "Effects of Physical Activity Application to Anthropological Status with Children, Youth and Adults" (148), Belgrade: Faculty of Sport and Physical Education.

Gardašević, J., Bjelica, D., \& Popović S. (2015). Efekti programiranog rada tokom pripremnog perioda na transformaciju agilnosti kod fudbalera kadetskog uzrasta. Sport Mont, XIII(43-45), 355-360.

Gardašević, J., Bjelica, D., \& Vasiljević, I. (2016a). Six-Week Preparation Period and its Effects on Transformation Movement Speed with Football Players Under 16. Sport Mont, 14(1), 13-16.
Gardašević, J., Bjelica, D., \& Vasiljević, I. (2016b). The Effects of the Training in the Preparation Period on the Repetitive Strength Transformation With Cadet Level Football Players. Book of Abstracts of the 13th International Scientific Conference on Transformation Processes in Sport "Sport Performance" (43). Podgorica: Montenegrin Sports Academy.

Gardasevic, J., Bjelica, D., Milasinovic, R., \& Vasiljevic, I. (2016). The Effects of the Training in the Preparation Period on the Repetitive Strength Transformation with Cadet Level Football Players. Sport Mont, 14(2), 31-33.

Gardaševic, J., \& Vasiljević, I. (2016). Effects of Preparation Period on Endurance in U16 Football Players. Book of Abstracts of the $4^{\mathrm{TH}}$ International Scientific Conference "Exercise and Quality of Life" (108). Novi Sad: Faculty of Sport and Physical Education.

Gardašević, J., Bjelica, D., Popović, S., \& Milašinović, R. (2016). Preparation Period and its Effects on the Speed of Ball Leading at Players U16. In Book of Summaries of 11th FIEP European Congress "Anthropological Aspects of Sport, Physical Education and Recreation" (30-31). Banjaluka: Faculty of Physical Education and Sport.

Gardasevic, J., Popovic, S., \& Bjelica, D. (2016). After preparation period ball shooting accuracy at players U15. In Abstract Book of the 8th Conference for Youth Sport (88). Ljubljana: Faculty of Sport.

Gardasevic, J., Bjelica, D., \& Vasiljevic, I. (2017a). The strength of kicking the ball after preparation period with $U 15$ football players. Book of Abstracts of the 14th International Scientific Conference on Transformation Processes in Sport "Sport Performance" (65-66). Podgorica: Montenegrin Sports Academy.

Gardasevic, J., Bjelica, D., \& Vasiljevic, I. (2017b). The Strength of Kicking the Ball after Preparation Period with U15 Football Players. Sport Mont, 15(2), 39-42.

Sermaxhaj, S., Popovic, S., Bjelica, D., Gardasevic, J., \& Arifi, F. (2017). Effect of recuperation with static stretching in isokinetic force of young football players. Journal of Physical Education and Sport, 17(3), 1948-1953. doi: 10.7752/jpes.2017.03191

Vasiljević, I., Gardašević, J., \& Bojanić, D. (2013). Uporedna analiza motoričkog prostora između aktivnih fudbalera kadetskog uzrasta i učenika srednje škole. Zbornik naučnih i stručnih radova VI međunarodni simpozijum "Sport i zdravlje" (212-215). Tuzla: Fakultet za tjelesni odgoj i sport.

Vasiljevic, I. (2017). Meta-analyze of the scientific papers on the effects of the preparation period on the basic motor skills of the cadet football players. Journal of Anthropology of Sport and Physical Education, 1(1), 2932. doi: 10.26773/jaspe.171005 